\title{
Professional burnout \\ - a comparative analysis \\ considering the selected sectors in Poland
}

Prof. Stanisław A. Witkowski Copper Region Vocational College (UZZM)

Ph D Magdalena Ślazyk-Sobol University of Wrocław Institute of Psychology

\section{Introduction}

The purpose of the article is to present the results of the empirical research devoted to the issues of "dysfunctional relations connected with professional work" (Maslach, Leiter, 2010, 2011), namely professional burnout among representatives of key professional groups in Poland. The authors of the publication focussed at the comparative analysis of people employed at various sectors of the economy considering interactions of subjective and organisational factors in the genesis of formation and development of the phenomenon of burnout and its components (emotional exhaustion, cynicism and reduced sense of personal achievements). In the present paper the results of the first part of the research will be presented only. The entire research procedure also covered its re-examination performed after the interval of nine months. The authors' intention is to present further findings of the research proceedings in the subsequent article.

The latest organisational approach of the phenomena of professional burnout provided by Maslach and Leiter $(2008,2010,2011)$ makes 
the grounds for the conceptualisation of the presented research. According to the researchers, people providing assistance to others are not the only ones who are affected by burnout. It also occurs within representatives of various professions due to an adequate matching of an employee (worker) and his / her workplace, resulting in emotional exhaustion. At this approach, occupational burnout is the opposite of commitment to work. According to the revised Maslach and Leiter concept, burnout is not only a problem of people but - above all - their social environment at which they work. There are just the structure and mechanism of operation of a particular workplace which shape interpersonal relationships in companies and influence the manner people do their work. The authors of the present article highlight a special role of the interaction of subjective and organisational factors in the process of development of the symptoms of burnout (it is reflected in the methodology of research).

\section{Methodology applied in the research}

Firstly, the authors formulated basic assumption, that professional burnout is a universal phenomenon occurring among employees / workers of various professional groups (including these being related to "providing assistance to others" (Malsach, 1998, Golembiewski and others, 1993).

Based on the literature in the field (in the first research proceeding) the following research hypotheses were also formulated:

H1: There are statistically significant dependencies between personality-related factors (features of the Big Five) and burnout components and professional burnout (Cherniss, 1993, Maslach, 1998).

H2: There are statistically significant dependencies between organisational factors (organisational climate indicators and organisational stress indicators) and the examined phenomenon (Cherniss, 1993, Maslach, 1998).

To measure the dependent variable, namely professional burnout, the latest version of the Maslach Burnout Inventory tool, the General Survey version, designed to examine representatives of various professional professions the licence - Agreement Number TA-207, MBI-GS, Polish, Mind Garden - was purchased) was applied. Other research tools to measure the independent variables were as follows: Questionnaire for examination of organisational climate by L. Rosenstiel (the Polish adaptation: S.A. Witkowski and P. Augustynowicz); Questionnaire of Organizational Stress Perception by S. Borucki (Borucki, 1988) and the NEO - PI - R Personality Inventory. 
Table 1. An operationalization of variables used in the research

\begin{tabular}{l|l}
\hline Emotional exhaustion & $\begin{array}{l}\text { The dependent variable, component } \\
\text { of professional burnout }\end{array}$ \\
\hline Cynicism & $\begin{array}{l}\text { The dependent variable, component } \\
\text { of professional burnout }\end{array}$ \\
\hline A sense of personal achievements & $\begin{array}{l}\text { The dependent variable, component } \\
\text { of professional burnout }\end{array}$ \\
\hline \multicolumn{2}{c}{ Independent variables, the roots of burn out } \\
\hline \multicolumn{2}{c}{ Personality traits and their components: }
\end{tabular}

Neuroticism , Extraversion, Openness, Conscientiousness, Agreeableness

Perception of organisational climate and its components:

Organisational climate - global scale, perception of co-workers, perception of supervisors organisation of work, flow of information and communication in a company, flow of information and communication in a company, representation of staff interests, possibility of career advancement and development

Organisational stress and its components:

Conflict of occupational role (external role conflict and personality role conflict, ambiguity of played occupational role and a sense of occupational role overload,

Source: own studies

The research was conducted in 2011 - 2012 within the following provinces: Lower Silesia, Cuyavia - Pomerania, Lesser Poland and Subcarpathian. 508 people in total representing various professional sectors (education, health care, trade and services, uniformed services, public administration) were examined.

At least six-month work experience made the criterion for the classification to the examined groups. $62,79 \%$ of all the respondents were employees with their work experience of 0,5 to 5 years. 196 men and 312 women participated in the research. Men employed in the field of uniformed services and - slightly - in the sector of trade and services predominated. The youngest participant of the research was 19 years old, the oldest one - 62 years old.

\section{Results of the research}

In order to determine all the variances between the sectors in the scope of the dependent variable (defined by three elements: emotional exhaustion, cynicism and a reduced sense of own professional effectiveness), a Chi-square test (otherwise known as Person's test of independence) with a coefficient 
of contingency measuring the strength of a particular dependency was applied.

Table 2. A level of emotional exhaustion within the professional sectors

\begin{tabular}{|c|c|c|c|c|c|c|}
\hline \multicolumn{7}{|c|}{ Chi-square $(8)=3,092, C=0,078, p=0,928$} \\
\hline \multirow{2}{*}{\multicolumn{3}{|c|}{ Emotional exhaustion }} & \multicolumn{3}{|c|}{ Result } & \multirow{3}{*}{$\frac{\text { Total }}{93}$} \\
\hline & & & \multirow{2}{*}{$\begin{array}{c}\text { low } \\
24\end{array}$} & \multirow{2}{*}{$\frac{\text { average }}{40}$} & \multirow{2}{*}{$\frac{\text { high }}{29}$} & \\
\hline Sector & administration & Population & & & & \\
\hline & & $\%$ within the sector & $25,8 \%$ & $43,0 \%$ & $31,2 \%$ & $100,0 \%$ \\
\hline & uniformed & Population & 35 & 49 & 31 & 115 \\
\hline & services & $\%$ within the sector & $30,4 \%$ & $42,6 \%$ & $27,0 \%$ & $100,0 \%$ \\
\hline & education & Population & 26 & 40 & 24 & 90 \\
\hline & & $\%$ within the sector & $28,9 \%$ & $44,4 \%$ & $26,7 \%$ & $100,0 \%$ \\
\hline & health care & Population & 20 & 43 & 27 & 90 \\
\hline & & $\%$ within the sector & $22,2 \%$ & $47,8 \%$ & $30,0 \%$ & $100,0 \%$ \\
\hline & services, trade & Population & 29 & 52 & 39 & 120 \\
\hline & & $\%$ within the sector & $24,2 \%$ & $43,3 \%$ & $32,5 \%$ & $100,0 \%$ \\
\hline \multirow[t]{2}{*}{ Total } & & Population & 134 & 224 & 150 & 508 \\
\hline & & $\%$ within the sector & $26,4 \%$ & $44,1 \%$ & $29,5 \%$ & $100,0 \%$ \\
\hline
\end{tabular}

Source: own studies

As shown in the table 2, the level of emotional exhaustion does not depend on any selected sector. Most often an average level of emotional exhaustion occurred within all the examined groups.

Table 3. A level of cynicism within the professional sectors

\begin{tabular}{|c|c|c|c|c|c|c|}
\hline \multicolumn{7}{|c|}{ Chi-square $(8)=14,648, C=0,167, p=0,066$} \\
\hline \multirow{2}{*}{\multicolumn{3}{|c|}{ Cynicism }} & \multicolumn{3}{|c|}{ Result } & \multirow{3}{*}{$\begin{array}{c}\text { Total } \\
93\end{array}$} \\
\hline & & & low & average & high & \\
\hline \multirow[t]{4}{*}{ Sector } & \multirow[t]{2}{*}{ administration } & Population & 16 & 49 & 28 & \\
\hline & & $\%$ within the sector & $17,2 \%$ & $52,7 \%$ & $30,1 \%$ & $100,0 \%$ \\
\hline & \multirow[t]{2}{*}{ uniformed services } & Population & 38 & 52 & 25 & 115 \\
\hline & & $\%$ within the sector & $33,0 \%$ & $45,2 \%$ & $21,7 \%$ & $100,0 \%$ \\
\hline
\end{tabular}




\begin{tabular}{|c|c|c|c|c|c|c|}
\hline \multirow[t]{6}{*}{ Sector } & \multirow[t]{2}{*}{ education } & Population & 19 & 47 & 24 & 90 \\
\hline & & $\%$ within the sector & $21,1 \%$ & $52,2 \%$ & $26,7 \%$ & $100,0 \%$ \\
\hline & \multirow[t]{2}{*}{ health care } & Population & 14 & 42 & 34 & 90 \\
\hline & & $\%$ within the sector & $15,6 \%$ & $46,7 \%$ & $37,8 \%$ & $100,0 \%$ \\
\hline & \multirow[t]{2}{*}{ services, trade } & Population & 30 & 56 & 34 & 120 \\
\hline & & $\%$ within the sector & $25,0 \%$ & $46,7 \%$ & $28,3 \%$ & $100,0 \%$ \\
\hline \multirow{2}{*}{\multicolumn{2}{|c|}{ Total }} & Population & 117 & 246 & 145 & 508 \\
\hline & & $\%$ within the sector & $23,0 \%$ & $48,4 \%$ & $28,5 \%$ & $100,0 \%$ \\
\hline
\end{tabular}

\section{Source: own studies}

These statistical results indicate that the level of cynicism recognised as the attitude of excessive distancing towards work also does not depend on any selected sector. However, a statistically significant tendency $(p<0,07)$ can be noticed - health care staff feel cynicism / depersonalisation most often and its low level most frequently occurs within uniformed serviced staff.

Table 4. A level of a sense of personal achievements within the professional sectors

\begin{tabular}{|c|c|c|c|c|c|c|}
\hline \multicolumn{7}{|c|}{ Chi-square $(8)=17,260, C=0,181, p=0,028$} \\
\hline \multirow{2}{*}{\multicolumn{3}{|c|}{ A sense of personal achievements }} & \multicolumn{3}{|c|}{ Result } & \multirow{3}{*}{$\begin{array}{c}\text { Total } \\
93 \\
\end{array}$} \\
\hline & & & \multirow{2}{*}{$\frac{\text { low }}{31}$} & \multirow{2}{*}{$\frac{\text { average }}{45}$} & \multirow{2}{*}{$\begin{array}{c}\text { high } \\
17\end{array}$} & \\
\hline Sector & administration & Population & & & & \\
\hline & & $\%$ within the sector & $33,3 \%$ & $48,4 \%$ & $18,3 \%$ & $100,0 \%$ \\
\hline & uniformed & Population & 36 & 56 & 23 & 115 \\
\hline & services & $\%$ within the sector & $31,3 \%$ & $48,7 \%$ & $20,0 \%$ & $100,0 \%$ \\
\hline & education & Population & 17 & 39 & 34 & 90 \\
\hline & & $\%$ within the sector & $18,9 \%$ & $43,3 \%$ & $37,8 \%$ & $100,0 \%$ \\
\hline & health care & Population & 18 & 47 & 25 & 90 \\
\hline & & $\%$ within the sector & $20,0 \%$ & $52,2 \%$ & $27,8 \%$ & $100,0 \%$ \\
\hline & services, trade & Population & 32 & 50 & 38 & 120 \\
\hline & & $\%$ within the sector & $26,7 \%$ & $41,7 \%$ & $31,7 \%$ & $100,0 \%$ \\
\hline \multirow[t]{2}{*}{ Total } & & Population & 134 & 237 & 137 & 508 \\
\hline & & $\%$ within the sector & $26,4 \%$ & $46,7 \%$ & $27,0 \%$ & $100,0 \%$ \\
\hline
\end{tabular}

Source: own studies

91 
On the grounds of the presented calculations it can be concluded that a high level of a sense of personal achievements $(37,8 \%)$ is characteristic to the educational sector and its low level occurs (in statistically significant terms) most often among uniformed services and administrative staff.

Table 5. A level of total professional burnout within the professional sectors

\begin{tabular}{|c|c|c|c|c|c|c|}
\hline \multicolumn{7}{|c|}{ Chi-square(8) $=25,983, C=0,221, p=0,001$} \\
\hline \multirow{2}{*}{\multicolumn{3}{|c|}{ Burnout - global effect }} & \multicolumn{3}{|c|}{ Result } & \multirow{3}{*}{$\frac{\text { Total }}{93}$} \\
\hline & & & \multirow{2}{*}{$\frac{\text { low }}{25}$} & \multirow{2}{*}{$\frac{\text { average }}{50}$} & \multirow{2}{*}{$\frac{\text { high }}{18}$} & \\
\hline Sector & administration & Population & & & & \\
\hline & & $\%$ within the sector & $26,9 \%$ & $53,8 \%$ & $19,4 \%$ & $100,0 \%$ \\
\hline & uniformed services & Population & 49 & 41 & 25 & 115 \\
\hline & & $\%$ within the sector & $42,6 \%$ & $35,7 \%$ & $21,7 \%$ & $100,0 \%$ \\
\hline & education & Population & 21 & 37 & 32 & 90 \\
\hline & & $\%$ within the sector & $23,3 \%$ & $41,1 \%$ & $35,6 \%$ & $100,0 \%$ \\
\hline & health care & Population & 15 & 46 & 29 & 90 \\
\hline & & $\%$ within the sector & $16,7 \%$ & $51,1 \%$ & $32,2 \%$ & $100,0 \%$ \\
\hline & services, trade & Population & 33 & 49 & 38 & 120 \\
\hline & & $\%$ within the sector & $27,5 \%$ & $40,8 \%$ & $31,7 \%$ & $100,0 \%$ \\
\hline Total & & Population & 143 & 223 & 142 & 508 \\
\hline & & $\%$ within the sector & $28,1 \%$ & $43,9 \%$ & $28,0 \%$ & $100,0 \%$ \\
\hline
\end{tabular}

Source: own studies

As shown above, at the level of statistical significance of $p=0,001$, an average level of total burnout most often occurs within all the examined sectors. However, burnout at such level is - as the researchers (Maslach et al., 1996) believe - a dangerous phenomenon and defined as an alarming signal to take preventive actions in companies / organisations. A high level of burnout most often occurs among employees / workers of the following sectors: education, health care as well as services and trade. Its low level - among officers of the Border Guard. At the further part of the statistical analysis of the research results, the general model (referring to the entire researched population) as well as minor dependency-based models for each of the groups - sectors were developed. The method of 10-fold validation was applied. A selection within the cases (examined 
people) was performed at random. 10 groups were drawn at first place. One of them - around 50 people - served as a testing group; other groups - as a learning sequence. Fully optimised multi-dimensional regression models were managed to be built in this manner. Similar patters were obtained for each of the sectors. They differ with predictors affecting the variability of the dependent variables which are presented below.

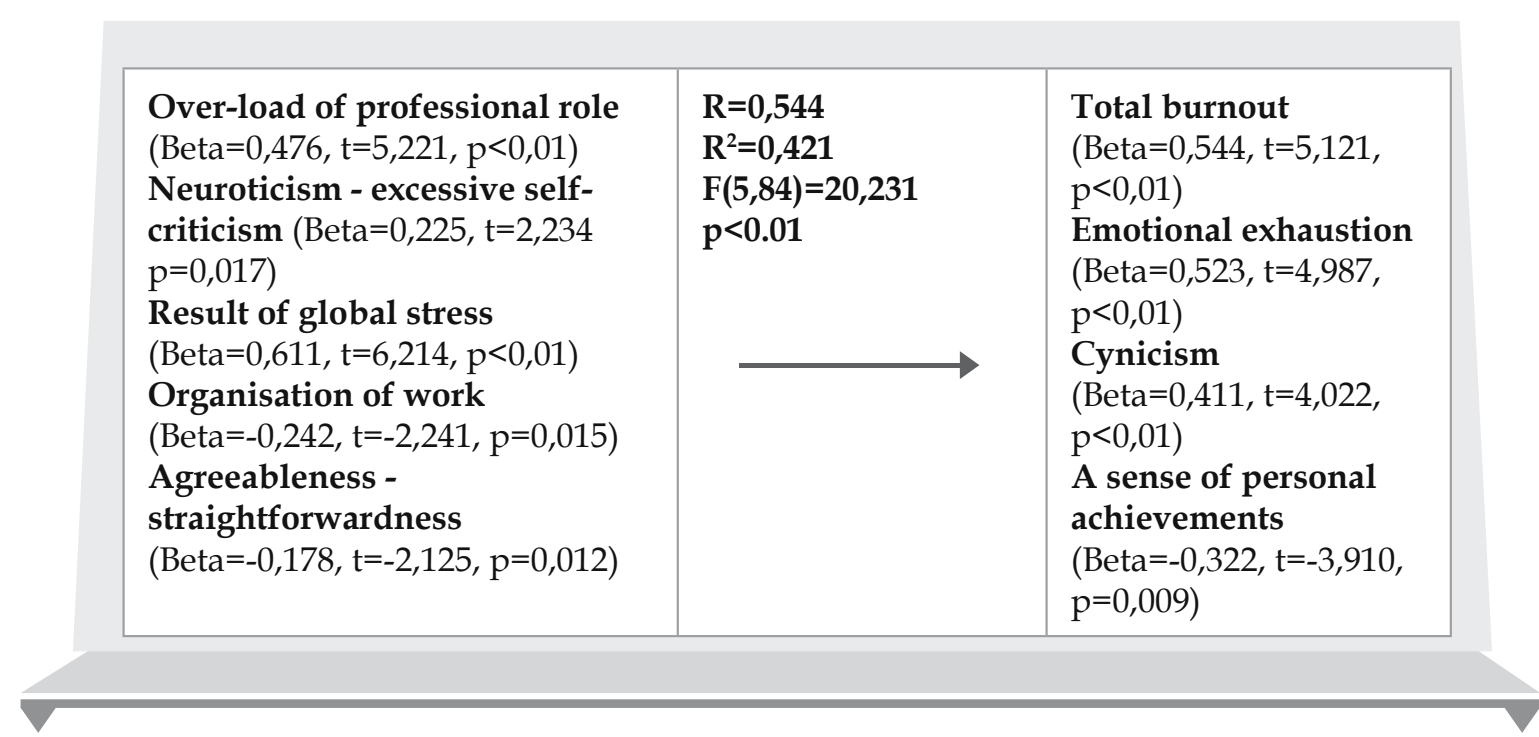

Figure 1. A dependency-based model for all the researched sectors

Source: own study

The above diagram presents the set of dependencies consisting of the following predictors: over-load of role, excessive self-criticism, global perception of organisational stress, work organisation and straightforwardness. The presented variables considerably contribute to professional burnout (they affect all the component of burnout at the strength of 0,544 ) and explained $42 \%$ of the dependent variable standing for the components of burnout. At the same time the independent variables interact with one another and the strength of all the relations among them and the strength of the impact onto the examined dependent variables are reflected by the Beta coefficient. The strongest predictor of professional burnout refers to organisational stress and over-load of professional burnout (one of the components of organisational stress perception according to Borucki, 1988). Also poor work organisation significantly, albeit at a lesser extent, affects the level of emotional exhaustion, cynicism, a sense of achievements and total burnout. When it comes to personality-based predictors 
which are characteristic to all the examined sectors, they are as follows: excessive self-criticism (a sense of shame and embarrassment in social situations) and straightforwardness (standing for: openness, innocence and sincerity) with are proportionally inverse in relation to the dependent variables). The lower level of the feature: straightforwardness, the higher level at the scale of professional burnout. All the predictors of burnout selected for staff of the following sector: administration are presented below.

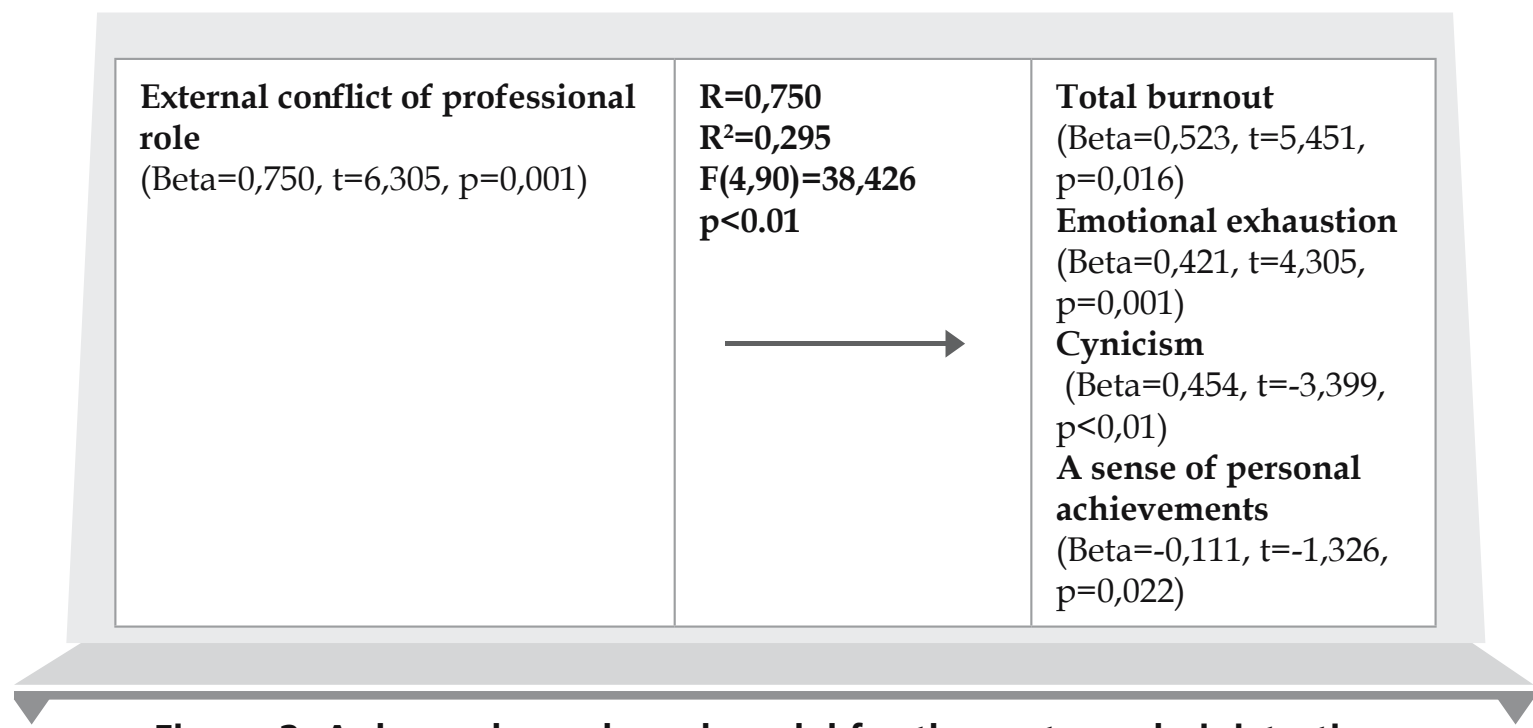

Figure 2. A dependency-based model for the sector: administration

Source: own study

The presented figure shows that the main and strongest predicator refers to the experience of external conflict of one's professional role. According to the concept by Z. Borucki (1988), an employee / worker feels organisational stress when he / she assesses external requirements as the ones exceeding his / her capabilities and his / her surroundings (work environment) as insufficient to fulfil needs. This is due to the lack of fit between an employee / worker and his / her environment. Moreover, transmitting the requirements of role takes various forms. It often happens that such employee / worker receives more than two transmissions of role from his / her superior at the same time (they can be contradictory or mutually exclusive). Such situation causes a conflict of role (RC). Borucki distinguished two types of these conflicts of role: personality-based one caused by personality-based conflict of the system of values, beliefs with regard to job positions and external one - caused by external sources such as superiors. In case of administration staff, this is the latter type of conflict of role which 
is the cause of professional burnout. At the strength of dependency of $R=0,550$ it affects the components of burnout and such dependency explains $29,5 \%$ of the variance of professional burnout. The following predictors of burnout were selected for the sector: uniformed services:

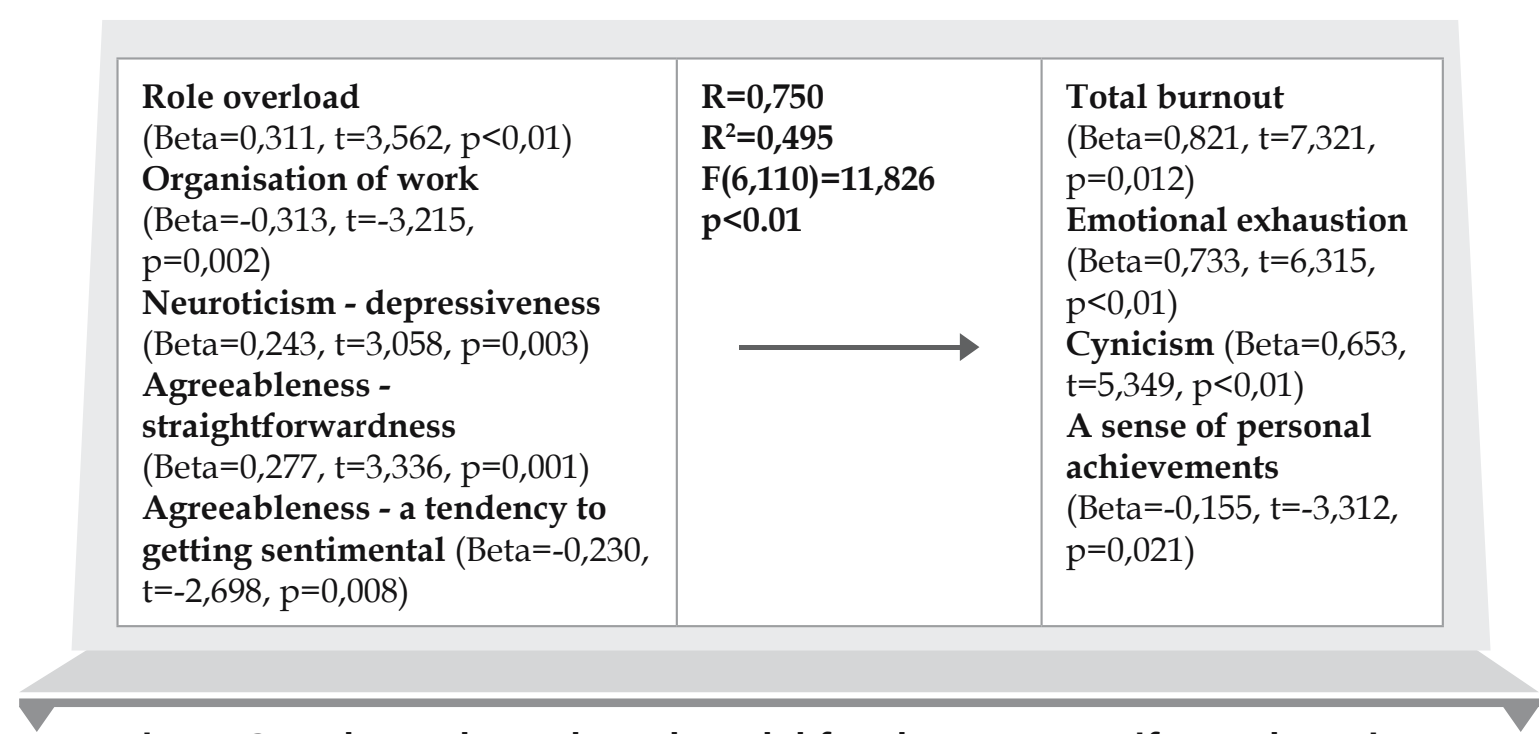

Figure 3. A dependency-based model for the sector: uniformed services

Source: own study

There is a larger group of various predictors of burnout in case of this professional group. They are both personality-based as well as organisational factors. The higher over-load of role and the poorer, worse assessed organisation of work as well as the higher depressiveness and altruism of officers as well as the lower tendency to get sentimental, the higher intensification of professional burnout comprehended as: higher exhaustion, cynicism and a reduced sense of personal achievements manifested in a low sense of own professional effectiveness. Over-load of professional role as well as organisation or work are organisational variables which most strongly interact with other independent variables and most strongly affect professional burnout. The impact of excess of duties and poor, under-effective organisation of work at particular components of burnout seems to be obvious. However, there is an interesting result referring to personality predisposition - a tendency to get sentimental - which is the cause of burnout within the occupational group. Perhaps the nature of provided services neither encourages nor requires the expression of emotions. It can be considered that showing feelings and surrendering oneself to emotions is socially undesirable in case of employees / workers whose job is to protect the country 
borders and to comply with all the procedures related to the border traffic. It is worth noting that $61 \%$ of the examined group were men and - considering gender variances - diverse emotional expressiveness of women and men should be regarded (Brannon 2002).

Other predictors were selected for the educational sector.

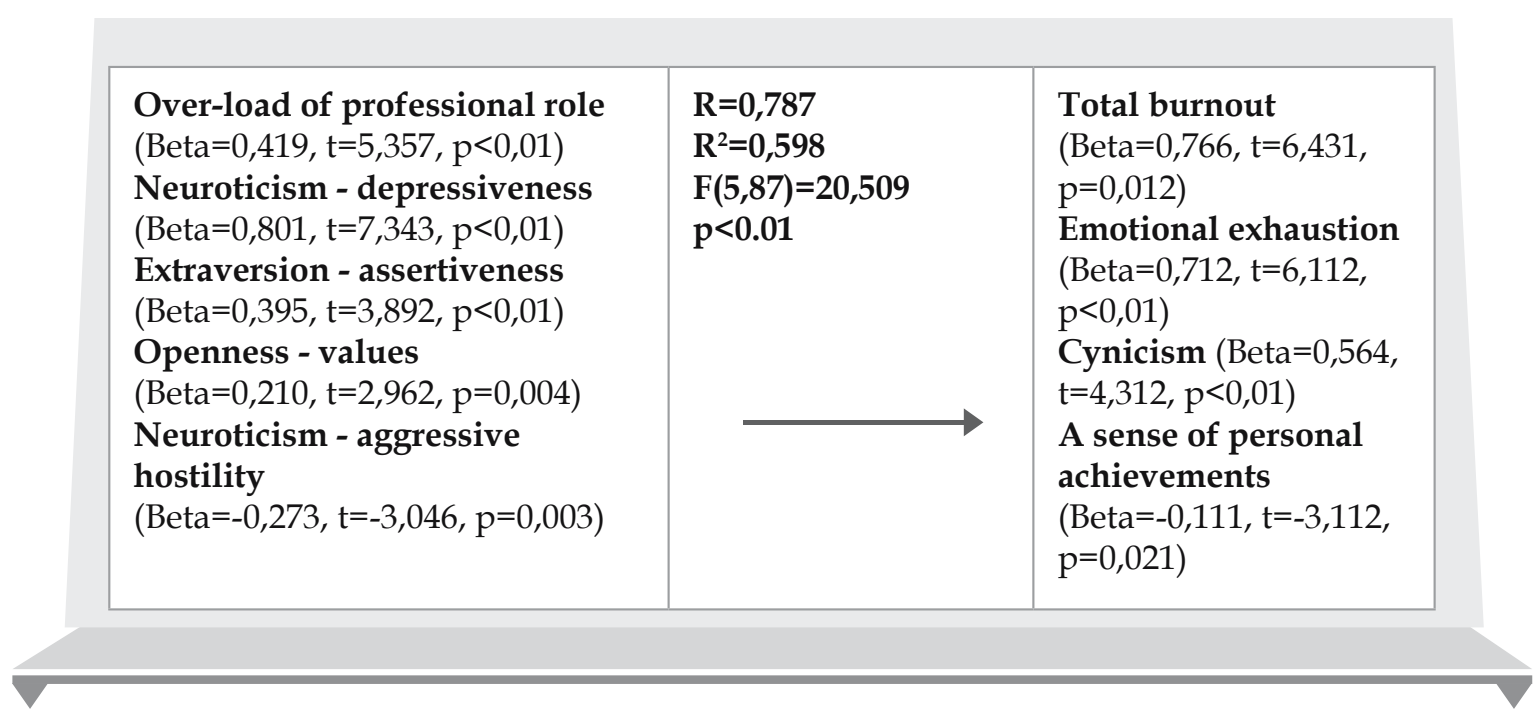

Figure 4. A dependency-based model for the sector: education

Source: own study

Incase of teachers, the prediction of professional burnout is significantly impacted by the following personality-based factors: depressiveness, assertiveness, openness for values and aggressive hostility, which varies from other personality-based features with its inversely proportional impact onto the dependent variables. It means that the lower level of the following feature: aggressive hostility represented by teachers, the stronger symptoms of burnout they experience. According to the authors of the NEO-PI-R tool applied for the diagnosis of personality-based features of all the examined people, aggressive hostility indicates a tendency to feel anger and other related states such as frustration and bitterness. This scale examined the readiness to experience anger (Costa, McCrae 2010). From the perspective of the obtained results, teachers who do not express their negative states should be more exposed to the presence of disturbed relations at work. The strongest personality-based predicator of burnout among teachers refers to depressiveness comprehended as "a tendency to fall into depressive moods (...) with a sense of guilt, sadness, hopelessness and loneliness (Costa, McCrae, ibid). Then, the overload of role related to excess of duties and a sense of lack of capabilities to meet all the assigned tasks is considered as an organisational predictor.

Another discussed group of predictors refers to health care staff. 


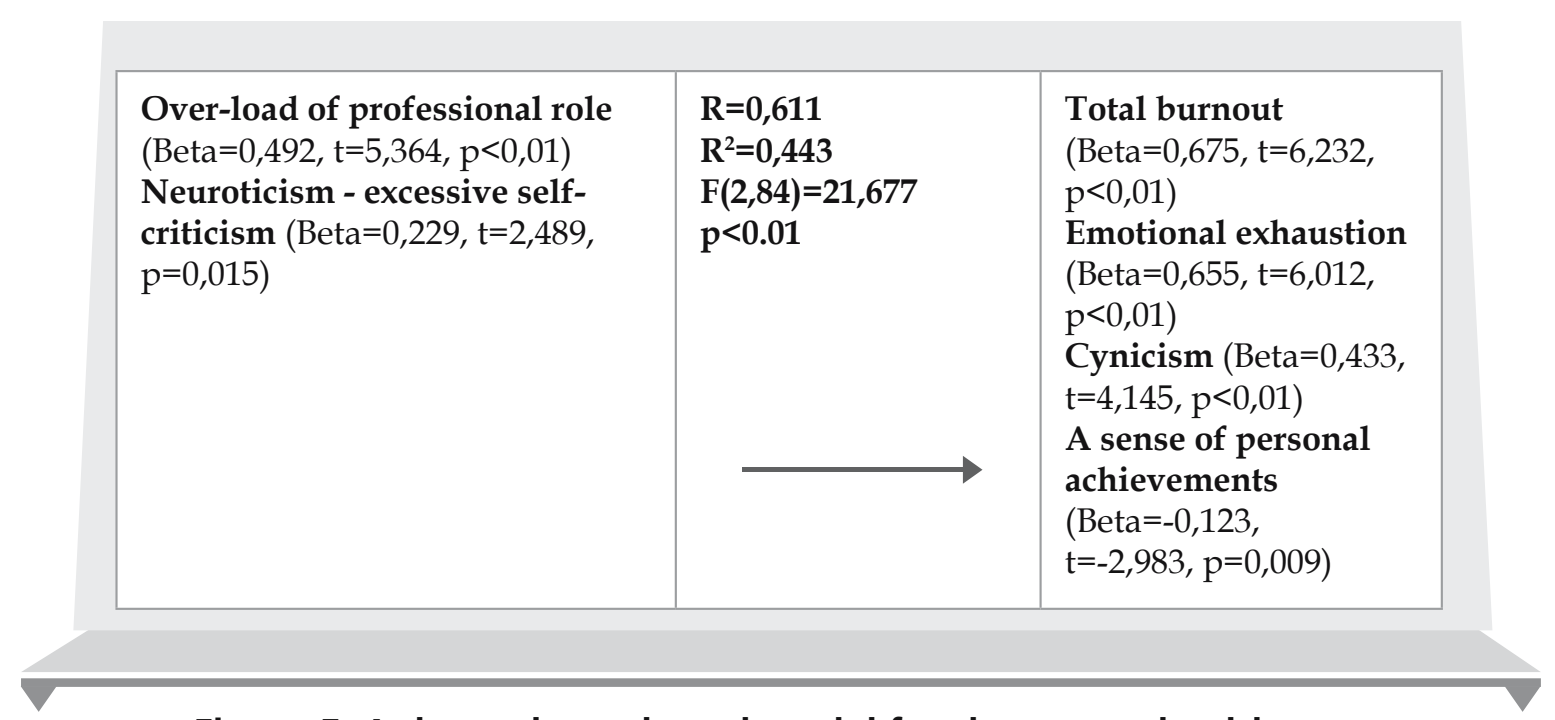

Figure 5. A dependency-based model for the sector: health care

Source: own study

In the field related to health care, the predictors of professional burnout and its components are as follows: over-load of professional role which - at the level of Beta $=0,492$ - affects the dependent variables and interacts with excessive criticism, which is the second predictor of the examined phenomenon. The formed variables with their strength of dependency at 0,611 affect all the components of burnout and explain as much as $44 \%$ of its variability. The last professional group is composed of trade and services staff:

\begin{tabular}{|c|c|c|}
\hline $\begin{array}{l}\text { Result of global organisational } \\
\text { stress } \\
\text { (Beta }=0,632, t=6,498, p<0,01 \text { ) } \\
\text { Organisation of work } \\
\text { (Beta }=-0,250, t=2,566, p=0,012) \\
\text { Agreeableness - } \\
\text { straightforwardness } \\
\text { (Beta }=-0,180, t=-2,247, p=0,027 \text { ) }\end{array}$ & $\begin{array}{l}R=0,598 \\
R^{2}=0,387 \\
F(3,113)=17,549 \\
p<0.01\end{array}$ & $\begin{array}{l}\text { Total burnout } \\
(\text { Beta }=0,616, t=6,231, \\
p=0,001) \\
\text { Emotional exhaustion } \\
\text { (Beta }=0,587, t=5,134, \\
p<0,01) \\
\text { Depersonalisation } \\
\text { (Beta }=0,511, t=4,122, \\
p<0,01) \\
\text { A sense of } \\
\text { achievements } \\
(\text { Beta }=-0,131, t=-3,433, \\
p=0,023)\end{array}$ \\
\hline
\end{tabular}

Figure 6. A dependency-based model for the sector: services / trade Source: own study

97 
Above all organisational factors such as organisational stress (globally) and organisation of work (which when negatively assessed by the staff will contribute to the symptoms of burnout) are the predictors of the phenomenon of professional burnout in the trade and services sector. In addition, the lower level of the following feature: straightforwardness among the sector staff, the higher risk of the occurrence of pathological symptoms of professional burnout. High levels at the scale of personality test are scored by truthful, sincere and honest people. The conducted analyses provide evidence that these personality characteristics can constitute sufficient resources to protect employees / workers from the risk of feeling disturbed relations at professional work. The impact of these predictors is at the level of $\mathrm{R}=0,598$ and they explain $38 \%$ of the variability of professional burnout.

\section{Summary}

The presented conclusions support the submitted research hypotheses. Professional burnout is a universal phenomenon with the occurrence of its symptoms being faced by both teachers, nurses and doctors as well as state administration, uniformed services and trade / services staff. A high level of cynicism was reported among health care staff; the lowest - among officers of the Border Guard. In turn, the highest sense of personal achievements was diagnosed among teachers. The lowest level of this component of professional burnout occurred in administration and among uniformed services staff. In general, the least burnt-out professional group turned out be officers of the Border Guard. This result is worth debating whether it is due to such their strong commitment to satisfying professional work ("military services") that their personal resources are not affected or whether the respondents did not wish to disclose their reasons for experiencing the syndrome of burnout which is considered to be a weakness.

The application conclusions resulted from the conducted research related primarily to the prophylaxis of professional burnout and preventive measures which could alleviate the symptoms of this dangerous phenomenon. Regardless of the place of employment, minimising the organisational stress and - above all - the over-load of professional role should be sought for. Employers and superiors should take care of considering physical and mental capabilities of employees / workers in terms of quantitatively and qualitatively adequate workload. It refers both to the excess of duties and setting realistic deadlines of executing tasks as well as delegating appropriate ranges of responsibilities, taking into account competence and maturity of subordinates. Providing safe and appropriate (to 
the specific sector) conditions, concern for job diversification - even through minor changes in activities or responsibilities - as well as - enabling employees / workers to perform entrusted tasks, without distracting them from aiming at the main objective(s) can lower their exhaustion and cynical - defensive attitude towards work. Also employers' / superiors' care for creating opportunities of development, granting bonuses or promotions as well as creating positive, subject-related atmosphere at the place of work will strengthen employees' / workers' professional involvement. The results referring to the personality-based predictors of burnout can also be useful at the process of building competence models as well as analysing job positions for HR selection.

In case of administration staff, the external conflict of professional role should be alleviated above all. It stands for caring for precise and unambiguous forms of delegating tasks and commands. All instructions, responsibilities and objectives should be consistent and understandable. Uniformed officers can be supported not only through organisational solutions regarding the over-load of role, creating opportunities of development and rewards as well as care for organisation of work and overall positive organisational atmosphere.

In the educational sector the symptoms of burnout can be alleviated through care for appropriate load of duties and responsibilities as well as supporting positive organisational climate. In the area of health care, preventive actions (apart from reinforcing organisational policies which are similar to other sectors) should be taken in order to weaken excessive self-criticism of employees / workers. It would be helpful to understand their own competencies, strengths and areas for improvement. In the trade and services sector, preventive actions could include organisational strategies presented for other professional groups. However, companies and organisations should especially take care of business ethics, promote the relevance and role of straightforward, honest practices and behaviours and sensitise subordinates with respect to them. Creating the clear and understandable system of values, positive examples of the key figures within these companies as well as encouraging to follow them can strengthen commitment to work and professional effectiveness of employees / workers within the economic sector.

\section{Summary}

\section{Professional burnout - a comparative analysis considering the key sectors in Poland}

The article presents the results of empirical research referring to the problem of burnout caused by professional burnout among staff of the most significant sectors in Poland. The authors presents the 
first part of the research project which also covered re-examination conducted after the interval of nine months. The research focused at the search for predictors of the phenomenon of burnout which - according to the latest concept of Maslach and Leiter - are as follows: emotional exhaustion, cynicism ad a reduced sense of personal achievements. With the application of neural networks, both the impact of organisational factors (organisational climate, experience of organisational stress) as well as personality-based factors onto the presence of professional burnout was verified. The main application conclusions resulted from the first stage of the research were presented at the end of the article.

Key words: professional burnout, organisational climate, organisational stress

\section{Streszczenie}

Wypalenie zawodowe - analiza porównawcza z uwzględnieniem głównych branż w Polsce

Artykuł przedstawia wyniki badań empirycznych dotyczących problematyki wypalenia pracą zawodową wśród pracowników najważniejszych branż w Polsce. Autorzy prezentują pierwszą część projektu badawczego, który obejmował także retest, przeprowadzony po dziewięciomiesięcznej przerwie. Badania koncentrowały się na poszukiwaniu predykatorów zjawiska wypalenia, które wg. najnowszej koncepcji Maslach i Leitera definiowane jest jako: wyczerpanie emocjonalne, cynizm oraz obniżone poczucie osiągnięć osobistych. Przy zastosowaniu sieci neuronowych zweryfikowano zarówno wpływ czynników organizacyjnych (klimat organizacyjny, doświadczenie stresu organizacyjnego) oraz osobowościowych na występowanie wypalenia zawodowego. $\mathrm{W}$ zakończeniu artykułu przedstawiono najważniejsze wnioski aplikacyjne wynikające $\mathrm{z}$ pierwszego etapu badań.

Słowa

kluczowe: $\quad$ wypalenie zawodowe, klimat organizacyjny, stres organizacyjny

\section{References}

1. Borucki Z. (1988), Stres organizacyjny: mechanizm, następstwa, modyfikatory. Gdańsk: Wydawnictwo Uniwersytetu Gdańskiego.

2. Brannon L. (2002), Psychologia rodzaju. Kobiety i mężczyźni:podobni czy różni. Gdańskie Wydawnictwo Psychologiczne. 
3. Cherniss C. (1993), Role of Professional self - efficacy In the etiology and ameliorationof burn - out, in: Schaufeli W.B., Maslach C., Marek T. (eds.).Proffessional Burnout: Recent Developments in Theory and Research, (p. 135 - 149). Washingotn, DC: Tylor \& Francis.

4. Costa P.T., Mc Crae R. (2010), NEO - PI - R. Podręcznik dla profesjonalistów. Inwentarz Osobowości NEO. Wersja Zrewidowana (NEO - PI - R) oraz Pięcioczynnikowy Inwentarz NEO (NEO-FFI). Warszawa: Pracownia Testów Psychologicznych

5. Golembiewski R.T., Scherb K, Boudreau R.A. (1993a), Burnout in cross national sttings. Generic and model - specific perspectives, in: Schaufeli W.B., Maslach C., Marek T. (eds.).Proffessional Burnout: Recent Developments in Theory and Research, (p. 217 - 236. Washingotn, DC: Tylor \& Francis

6. Maslach Ch., Jackson S.E, Leiter M. (1996). MBI Manual. 3rd ed. Mountain View, CA:CPP, Inc.

7. Maslach Ch. (1998), A Multidimensional Theory of Burnout, in: Cooper C.L. (ED.). Theories of organizational stress, (p. 68 - 85). New York: Oxford University Press

8. Maslach Ch, Leiter M.P. (2008), Early predictors of Job burnout and engagement. Journal of Applied Psychology. Vol., 93, No 3, (p. 498 - 512).

9. Maslach Ch., Leiter M.P. (2010), Pokonać wypalenie zawodowe. Sześć strategii poprawiania relacji z praca. Warszawa: Oficyna Wolters Kluwer business.

10. Maslach Ch., Leiter M.P. (2011), Prawda o wypaleniu zawodowym. Co robić ze stresem w organizacji. Warszawa: Wydawnictwo Naukowe PWN. 